\title{
L-Arginine transport and metabolism in Giardia intestinalis support its position as a transition between the prokaryotic and eukaryotic kingdoms
}

\author{
Leigh A. Knodler, Philip J. Schofield and Michael R. Edwards \\ Author for correspondence: Michael R. Edwards. Tel: +61 23852017. Fax: +6123136271. \\ e-mail: M.Edwards@unsw.EDU.AU
}

School of Biochemistry and Molecular Genetics, University of New South Wales, Sydney, NSW 2052, Australia

\begin{abstract}
Arginine is metabolized by the arginine dihydrolase pathway in Giardia intestinalis trophozoites and is an important metabolic fuel for this parasite. Radiolabelled arginine was used to characterize the transport of arginine into Giardia intestinalis trophozoites. The transporter had a high affinity for arginine $\left(K_{m} 15 \mu \mathrm{M}\right)$ and a high activity $\left[V_{\max } 76 \mathrm{nmol} \mathrm{min}^{-1}(\mathrm{mg} \text { protein) })^{-1}\right.$ at $25^{\circ} \mathrm{C}$. Substrate specificity studies indicated an absolute requirement for the $\alpha$-amino and carboxyl groups, but a tolerance for some substitutions in the guanidino group. The use of non-metabolized arginine analogues in combination with HPLC amino acid analysis of intra- and extracellular pools demonstrated that the arginine transporter is an arginine-ornithine antiport. Investigations of the first step of arginine metabolism, involving arginine deiminase, revealed a relatively high affinity for arginine $\left(K_{m} 0.16 \mathrm{mM}\right)$ and a large maximal velocity $\left[V_{\max } 550 \mathrm{nmol} \mathrm{min}^{-1}(\mathrm{mg} \text { protein) })^{-1}\right.$ at $37^{\circ} \mathrm{C}$ ]. Substrate specificity studies showed that the arginine deiminase had a characteristically different substrate recognition profile to that of the arginine transporter. Overall, the combination of the transporter and the deiminase result in very low intracellular arginine concentrations and their properties are consistent with the rapid transport of arginine for metabolism via the arginine dihydrolase pathway.
\end{abstract}

Keywords: arginine transport, arginine deiminase, Giardia intestinalis

\section{INTRODUCTION}

Arginine is a major nutrient for many organisms and cells. However, in order for it to be utilized, there must be an appropriate mechanism for transporting the arginine from the external medium to the intracellular milieu, where it can be metabolized. The mechanism of transmembrane transport of arginine varies from prokaryotes to eukaryotes. For some prokaryotes, such as Pseudomonas and Streptococcus spp., arginine can be metabolized via the arginine dihydrolase pathway (Cunin et al., 1986). In these cases, the transport of arginine is via an arginine-ornithine antiporter which accumulates arginine in exchange for intracellular ornithine, an end product of the arginine dihydrolase pathway (Driessen et al., 1987; Bourdineaud et al., 1993). For most eukaryotes, arginine transport involves the $\mathrm{y}^{+}$system, which is a high-affinity, sodiumindependent system, specific for cationic amino acids
(White, 1985). There is no evidence to date of this being an obligatory arginine-ornithine antiporter.

The metabolism of arginine by the eukaryotic protozoan parasite Giardia intestinalis is unusual. The arginine dihydrolase pathway, which is normally confined to the prokaryotic kingdom, is operational in G. intestinalis and is a major route for energy production (Schofield $e t$ al., 1992). However, recent evidence places Giardia on one of the earliest diverging branches of the evolutionary tree (Sogin et al., 1989), and as such it may show metabolic and physiological properties characteristic of a transition between the eukaryotic and prokaryotic kingdoms.

We report in this paper the characterization of the arginine transporter in $G$. intestinalis and, on the basis of substrate specificity and kinetic studies, distinguish its properties from those of arginine deiminase, which is the first step of arginine metabolism. We propose that the transport 
system is an arginine-ornithine antiport, which is prokaryotic in nature and may be related to the bacterial transporters previously described for Streptococcus lactis (Driessen et al., 1987) and Pseudomonas aeruginosa (Bourdineaud et al., 1993).

\section{METHODS}

Parasites and materials. Giardia intestinalis trophozoites (Portland 1 strain) were grown in TYI-S-33 medium supplemented with ox bile as described previously (Knodler et al., 1994). Whole-cell suspensions were prepared in phosphatebuffered saline (PBS) $\left[1.8 \mathrm{mM} \mathrm{KH}_{2} \mathrm{PO}_{4} / 5 \mathrm{mM} \mathrm{K} \mathrm{HPO}_{4} / 0.9 \%\right.$ $(\mathrm{w} / \mathrm{v}) \mathrm{NaCl} \mathrm{pH} \mathrm{7.4]} \mathrm{and} \mathrm{left} \mathrm{on} \mathrm{ice} \mathrm{until} \mathrm{required.} \mathrm{Protein}$ concentrations of whole-cell suspensions were determined by the Lowry method. L- $\left[2,3,4,5-{ }^{3} \mathrm{H}\right]$ Arginine and $\mathrm{DL}-[1-$ ${ }^{14} \mathrm{C}$ ]ornithine were obtained from Amersham. L-[ureido$\left.{ }^{14} \mathrm{C}\right]$ Citrulline and $\mathrm{L}-\left[\mathrm{U}-{ }^{14} \mathrm{C}\right]$ arginine were purchased from $\mathrm{NEN}$ Research Products. All arginine analogues were obtained from Sigma. Silica gel TLC plates were from Merck.

Uptake assays. The centrifugation through oil method (Edwards et al., 1993) was routinely used to monitor arginine uptake. Standard assay conditions were $0.13 \mathrm{mg}$ cell protein in a total volume of $200 \mu \mathrm{l}$ PBS containing $100 \mu \mathrm{M}$ L- $[2,3,4,5-$ $\left.{ }^{3} \mathrm{H}\right]$ arginine $\left(10 \mathrm{mCi} \mathrm{mmol}^{-1}\right)$ at a temperature of $25^{\circ} \mathrm{C}$. The initial rate of uptake was normally measured over the first $4 \mathrm{~s}$ after mixing. Samples were processed as described previously (Edwards et al., 1993). For kinetic studies, the arginine concentration was varied accordingly, whilst keeping the specific activity constant. The timepoint was set to $4 \mathrm{~s}$ and in a total assay volume of $200 \mu \mathrm{l}, 0.13 \mathrm{mg}$ cell protein was routinely used. The $K_{\mathrm{m}}$ for arginine uptake was determined by computer fit to the Michaelis-Menten equation. For investigating the substrate specificity of the transporter, the initial rate of uptake of $100 \mu \mathrm{M} \mathrm{L}-\left[2,3,4,5-{ }^{3} \mathrm{H}\right]$ arginine at $25^{\circ} \mathrm{C}$ was measured over $4 \mathrm{~s}$ in the presence or absence of potential competitors $(5 \mathrm{mM})$. After $5 \mathrm{~min}$ preincubation at $25^{\circ} \mathrm{C}$, cells were added to the analogue-containing permeant mix, to initiate the assay. The graphical method of Hunter \& Downs (1945) was used to determine $K_{1}$ values for a number of arginine analogues affecting arginine uptake. This method involves measuring the initial rate of arginine uptake at a number of fixed arginine concentrations $\left(25-200 \mu \mathrm{M} ; 40 \mathrm{mCi} \mathrm{mmol}^{-1}\right)$ in the presence of various inhibitor concentrations as indicated. This method distinguished between competitive and non-competitive inhibition and allowed the graphical determination of $K_{i}$.

Determination of metabolism during arginine uptake. A modification of the centrifugation through oil method was used to investigate the intracellular metabolism of arginine. The cells $(0 \cdot 2-0 \cdot 3 \mathrm{mg}$ protein in $100 \mu \mathrm{l} \mathrm{PBS})$ and $\mathrm{L}-\left[\mathrm{U}-{ }^{14} \mathrm{C}\right]$ arginine $\left(200 \mu \mathrm{M}, 5 \mathrm{mCi} \mathrm{mmol}^{-1}\right.$ in $\left.100 \mu \mathrm{l} \mathrm{PBS}\right)$ were incubated separately at $25^{\circ} \mathrm{C}$ for $5 \mathrm{~min}$ to allow temperature equilibration. Cells were then added to the permeant to initiate the reaction and at the required time point (up to $30 \mathrm{~s}$ ), centrifuged through an oil layer (Edwards et al., 1993) into $40 \mu \mathrm{l} 5 \%(\mathrm{v} / \mathrm{v})$ perchloric acid to stop any further metabolism. The supernatant was aspirated and the oil layer washed twice with distilled water, and finally the oil layer was removed by aspiration. To the perchloric acid layer was added $40 \mu \mathrm{l} 1 \mathrm{M} \mathrm{KOH} / 1 \mathrm{M} \mathrm{KHCO}_{3}$ and $3 \mu \mathrm{l}$ arginine, ornithine and citrulline tracer mix (containing $10 \mathrm{nmol}$ of each amino acid). This was vortexed and left on ice for $15 \mathrm{~min}$. After centrifugation, a $65 \mu \mathrm{l}$ sample of clear supernatant was vacuum-dried on a Speed Vac concentrator. The dried pellet was resuspended in $25 \mu \mathrm{l} 0 \cdot 1 \mathrm{M} \mathrm{HCl}$ and then centrifuged for $5 \mathrm{~s}$. A $5 \mu \mathrm{l}$ sample of supernatant was spotted onto one corner of a $10 \mathrm{~cm} \times 10 \mathrm{~cm}$ silica gel 60 TLC plate. The amino acids were separated in the first dimension by chloroform/ methanol $/ 17 \%(\mathrm{v} / \mathrm{v})$ ammonia $(2: 2: 1$, by vol.) and in the second dimension by phenol/water $(3: 1, \mathrm{w} / \mathrm{v})$. The plates were air-dried, pretreated with $10 \%(\mathrm{v} / \mathrm{v})$ triethylamine in dichloromethane and then sprayed with $0.01 \%$ fluorescamine in acetone to visualize the amino acids. The location of the radioactivity was determined by PhosphorImager analysis. Amino acids were identified by comparison to radiolabelled arginine, ornithine and citrulline standards chromatographed under the same conditions. Concurrent experiments were conducted to determine the total radioactivity accumulated in the cell pellet. A $20 \mu \mathrm{l}$ aliquot of the unneutralized perchloric acid layer was added to $10 \mathrm{ml}$ scintillant $[0.5 \%(\mathrm{w} / \mathrm{v})$ diphenyloxazole in $1: 2$ $(\mathrm{v} / \mathrm{v})$ Triton X-100/toluene] and the radioactivity determined.

Amino acid analyses. Cells $(0.3 \mathrm{mg}$ cell protein) were incubated in PBS with a non-metabolizable arginine analogue (at a final concentration of $1 \mathrm{mM}$ ) at $25^{\circ} \mathrm{C}$ in a total assay volume of $200 \mu \mathrm{l}$. At the required time point, the reaction was terminated by centrifugation through an oil layer (Edwards $e$ t al., 1993) into $40 \mu \mathrm{l} 20 \%$ (w/v) sulphosalicylic acid. The pellet samples were then processed as outlined previously (Knodler et al., 1994) and analysed using a Beckman system 6300 amino acid analyser. Standard solutions of each arginine analogue were assayed so that the concentration of accumulated analogue expressed as $\mathrm{nmol}$ (mg protein $)^{-1}$ could be determined.

Enzyme assays. Cell extracts were prepared in $40 \mathrm{mM}$ HEPES $\mathrm{pH} 7.0$ by sonication of whole cells with a Branson sonifier 250 ( $30 \%$ duty cycle, output $2-3,1 \mathrm{~min}$ ). Protein in cell extracts was determined by the method of Bradford (1976). Arginine deiminase was routinely assayed by the colorimetric determination of citrulline as described previously (Schofield et al., 1992), except that $40 \mathrm{mM}$ HEPES buffer $\mathrm{pH} 7 \cdot 0$ replaced $40 \mathrm{mM}$ MES buffer $\mathrm{pH} 7 \cdot 0$. In inhibition studies, the production of citrulline was measured over a $10 \mathrm{~min}$ time period at $37^{\circ} \mathrm{C}$ with $1 \mathrm{mM}$ arginine and $0.1 \mathrm{mg}$ protein, in the presence or absence of potential competitors $(10 \mathrm{mM})$. For $K_{\mathrm{m}}$ determinations the more sensitive colorimetric assay of Prescott \& Jones (1969) was used, since the method of Boyde \& Rahmatullah (1980) proved unsuitable due to poor sensitivity at the low arginine concentrations required for kinetic studies. The initial rate of arginine deiminase activity was measured over a $2.5 \mathrm{~min}$ time period at $37^{\circ} \mathrm{C}$ using a range of arginine concentrations from 0.07 to $1 \mathrm{mM}$ and $0.04 \mathrm{mg}$ protein.

\section{RESULTS}

\section{Arginine transport and metabolism}

The centrifugation through oil method proved very reliable for assaying the uptake of arginine over short time periods. Uptake was monitored using L-[2,3,4,5$\left.{ }^{3} \mathrm{H}\right]$ arginine. The uptake of $100 \mu \mathrm{M}$ arginine was very rapid, with linearity at $25^{\circ} \mathrm{C}$ extending to $8 \mathrm{~s}$ only (Fig. 1). Over a $30 \mathrm{~s}$ time period, radioactivity was reproducibly accumulated to levels of approximately $20 \mathrm{nmol}$ arginine $(\mathrm{mg} \text { protein })^{-1}$. The uptake of arginine was much slower at $4{ }^{\circ} \mathrm{C}$ (Fig. 1).

The extent of arginine metabolism at a number of points over a $30 \mathrm{~s}$ time course was investigated via the accumulation of $\left[\mathrm{U}-{ }^{14} \mathrm{C}\right]$ arginine $(100 \mu \mathrm{M})$, instead of $\left[{ }^{3} \mathrm{H}\right]$ arginine, and determining the products by TLC analysis. The results are presented in Table 1 . The zero timepoint was representative of the time required for the 


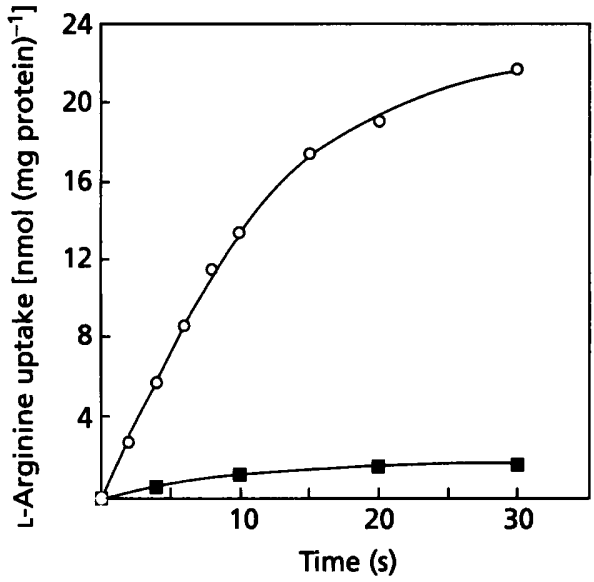

Fig. 1. Time course of uptake of $100 \mu \mathrm{M}$ arginine uptake by $\mathbf{G}$. intestinalis trophozoites at $25^{\circ} \mathrm{C}(\mathrm{O})$ and $4^{\circ} \mathrm{C}(\square)$. Cells were incubated with $\mathrm{L}-\left[2,3,4,5-{ }^{3} \mathrm{H}\right]$ arginine and at specific time points centrifuged to the bottom of an oil layer. The amount of radioactivity accumulated in the cell pellet was determined. Results are the mean of triplicate timepoints from a single representative experiment; further repeats showed less than $20 \%$ variation in the $4 \mathrm{~s}$ timepoint.

Table 1. Profile of ${ }^{14} \mathrm{C}$-labelled metabolites following uptake of $\left[\mathrm{U}-{ }^{14} \mathrm{C}\right]$ arginine by $\mathrm{G}$. intestinalis trophozoites at $25^{\circ} \mathrm{C}$

Intact cells were incubated with $\mathrm{L}-\left[\mathrm{U}-{ }^{14} \mathrm{C}\right]$ arginine at a final concentration of $100 \mu \mathrm{M}$. At specific time points the cells were centrifuged through an oil layer into $40 \mu \mathrm{l} 5 \%(\mathrm{v} / \mathrm{v})$ perchloric acid. The oil layer was washed and removed by aspiration, and then $40 \mu \mathrm{l} 1 \mathrm{M} \mathrm{KOH} / 1 \mathrm{M} \mathrm{KHCO}_{3}$ was added with an amino acid tracer mix. This was vortexed, left on ice for $15 \mathrm{~min}$, and then centrifuged at $16000 \mathrm{~g}$ for $3 \mathrm{~min}$. A $65 \mu \mathrm{l}$ sample of clear supernatant was vacuum-dried and then resuspended in $25 \mu \mathrm{l}$ $0 \cdot 1 \mathrm{M} \mathrm{HCl}$. After a quick centrifugation, a $5 \mu \mathrm{l}$ sample was spotted onto a $10 \mathrm{~cm} \times 10 \mathrm{~cm}$ silica gel TLC plate. The amino acids were separated in two dimensions and after drying the plate the radioactivity was located by PhosphorImager analysis. Values are means of results $\pm S D$ from at least four separate experiments.

\begin{tabular}{|llll|}
\hline $\begin{array}{l}\text { Time } \\
\text { point } \\
\text { (s) }\end{array}$ & \multicolumn{3}{c|}{$\begin{array}{c}\text { Metabolite (\% of } \\
\text { accumulated radioactivity) }\end{array}$} \\
\cline { 2 - 4 } & Arginine & Citrulline & Ornithine \\
\hline 0 & $24 \pm 5.5$ & $79 \pm 7.8$ & $1.5 \pm 1.8$ \\
4 & $16 \pm 2.2$ & $85 \pm 4.7$ & $1.8 \pm 2 \cdot 2$ \\
10 & $4.3 \pm 2.5$ & $93 \pm 3.6$ & $3.3 \pm 1.8$ \\
30 & $1.2 \pm 0.7$ & $97 \pm 1.4$ & $1.9 \pm 1 \cdot 1$ \\
\hline
\end{tabular}

centrifuge to reach a sufficient velocity in order to pellet the cells and was estimated to be approximately $3 \mathrm{~s}$. Over a $30 \mathrm{~s}$ time period, the proportion of radiolabel in arginine decreased but was always relatively low, with only $15 \%$ of the total incorporated radioactivity unmetabolized as arginine after $4 \mathrm{~s}$. The majority of the intracellular radioactivity ( $>80 \%$ ) was present as citrulline, which is the first breakdown product of arginine metabolism by the action of arginine deiminase. HPLC amino acid analysis confirmed that the major proportion of transported arginine was present as intracellular citrulline, with the absolute amount of accumulated citrulline corresponding to the amount of $\left[{ }^{3} \mathrm{H}\right]$ arginine transported. Only minimal quantities [less than $1 \mathrm{nmol}(\mathrm{mg} \text { protein })^{-1}$ ] of intracellular arginine could be detected by amino acid analysis over the $30 \mathrm{~s}$ time period studied. The proportion of radiolabel present as citrulline was relatively constant over the 30 s time period (between 79 and $97 \%$ ). There was little incorporation of radiolabel into intracellular ornithine over the time course studied. TLC and PhosphorImager analysis of incubation medium showed that approximately $8 \%$ and $20 \%$ of the arginine taken up appeared as extracellular ornithine after $4 \mathrm{~s}$ and $30 \mathrm{~s}$ respectively.

The initial rate of arginine uptake ( $4 \mathrm{~s}$ time point) at $25^{\circ} \mathrm{C}$ over an arginine concentration range of 7-50 $\mu \mathrm{M}$ showed saturability with respect to arginine. Kinetic analysis from two separate experiments gave $K_{\mathrm{m}}$ values of $15 \pm 4 \mu \mathrm{M}$ and $15 \pm 1 \mu \mathrm{M}$ and $V_{\max }$ values of $75 \pm 9 \mathrm{nmol} \mathrm{m^{-1 }}(\mathrm{mg}$ protein) $)^{-1}$ and $76 \pm 2 \mathrm{nmol} \mathrm{min}^{-1}(\mathrm{mg} \text { protein) })^{-1}$ for arginine uptake. Linearity over the $4 \mathrm{~s}$ time period was confirmed for both ends of the concentration range (results not shown). Investigation by TLC of the extent of arginine metabolism at the lowest concentration used $(7 \mu \mathrm{M})$ revealed that $89 \%$ of the radiolabelled arginine had been converted to citrulline within $4 \mathrm{~s}$, but no labelled ornithine could be detected (results not shown).

\section{Specificity of arginine uptake}

The uptake of $100 \mu \mathrm{M} \mathrm{L}-\left[2,3,4,5{ }^{3} \mathrm{H}\right]$ arginine over a $4 \mathrm{~s}$ time period was monitored in the presence and absence of a number of potential inhibitors and substrates of the arginine transporter, all at a final concentration of $5 \mathrm{mM}$. Inhibition of arginine uptake would suggest competition and binding to the transporter, with the possibility of transport into the cell and subsequent inhibition of the arginine deiminase. The results are presented in Table 2. Alteration or removal of the $\alpha$-amino group of arginine, as in 4-guanidinobutyric acid and $N^{\alpha}$-acetyl-L-arginine, gave no inhibition of arginine uptake. Removal of the carboxyl group also resulted in relatively little inhibition of arginine uptake.

Removal or attenuation of the guanidino group and alteration of the number of methylene groups in the side chain of arginine had varying effects. L-Ornithine, which has the same number of methylene groups as arginine, but has the guanidino group replaced by an amino group, strongly inhibited arginine uptake. Altering the number of methylene groups decreased the inhibition (e.g. L-2,4diaminobutyric acid and lysine). Substituting the guanidino group of arginine with a methyl group ( $N^{\mathrm{G}}$ methyl-L-arginine) resulted in strong inhibition of arginine uptake. However, substitution by a nitro group 
Table 2. Inhibition of arginine uptake in G. intestinalis trophozoites and giardial arginine deiminase activity by various arginine analogues

The initial rate of uptake of $100 \mu \mathrm{M}\left[{ }^{3} \mathrm{H}\right]$ arginine over a $4 \mathrm{~s}$ time period was studied in the presence and absence of various arginine analogues at a concentration of $5 \mathrm{mM}$. The influence of arginine analogues at a final concentration of $10 \mathrm{mM}$ on the activity of arginine deiminase from $G$. intestinalis with $1 \mathrm{mM}$ arginine at $37^{\circ} \mathrm{C}$ over $10 \mathrm{~min}$ was also studied. In both cases the results are presented as a percentage of the rate in the absence of competitor. The $K_{1}$ values for competition of arginine uptake were determined by the method of Hunter \& Downs (1945). All compounds were the L-isomer unless otherwise stated. All values are means \pm SD from at least three separate determinations. ND, Not determined since these compounds interfere with the chromogenic assay system; ADI, arginine deiminase.

\begin{tabular}{|c|c|c|c|}
\hline Analogue & $\begin{array}{l}\text { Uptake } \\
\text { rate } \\
\text { (\% of } \\
\text { control) }\end{array}$ & $\begin{array}{c}K_{\mathrm{i}} \\
(\mu \mathrm{M})\end{array}$ & $\begin{array}{c}\text { ADI } \\
\text { activity } \\
\text { ( } \% \text { of } \\
\text { control) }\end{array}$ \\
\hline \multicolumn{4}{|l|}{$\alpha$-Amino group blocked or absent } \\
\hline 4-Guanidinobutyric acid & $97 \pm 5$ & & $96 \pm 4$ \\
\hline$N^{\alpha}$-Acetylarginine & $104 \pm 7$ & & $96 \pm 7$ \\
\hline$N^{\alpha}$-Carbamylarginine & $71 \pm 6$ & & ND \\
\hline \multicolumn{4}{|l|}{$\alpha$-Carboxyl group absent } \\
\hline Agmatine & $73 \pm 7$ & & $55 \pm 1$ \\
\hline Putrescine & $80 \pm 4$ & & $54 \pm 10$ \\
\hline \multicolumn{4}{|c|}{ Guanidino group altered or absent } \\
\hline Lysine & $37 \pm 5$ & & $100 \pm 9$ \\
\hline Ornithine & $20 \pm 1$ & $272 \pm 26$ & $24 \pm 10$ \\
\hline 2,4-Diamino-n-butyric acid & $62 \pm 4$ & & $24 \pm 7$ \\
\hline DL-2,3-Diaminopropionic acid & $97 \pm 6$ & & $106 \pm 6$ \\
\hline Norvaline & $95 \pm 4$ & & $73 \pm 9$ \\
\hline Leucine & $99 \pm 3$ & & $95 \pm 3$ \\
\hline Alanine & $103 \pm 6$ & & $92 \pm 9$ \\
\hline$N^{\varepsilon}$-Methyllysine & $20 \pm 4$ & $170 \pm 20$ & $99 \pm 2$ \\
\hline$N^{\mathrm{G}}$-Methylarginine & $4 \pm 3$ & $18 \pm 8$ & $76 \pm 8$ \\
\hline$N^{G}$-Nitroarginine & $74 \pm 8$ & & $5 \pm 1$ \\
\hline Citrulline & $100 \pm 6$ & & ND \\
\hline \multicolumn{4}{|l|}{ Side chain altered } \\
\hline Canavanine & $13 \pm 1$ & $137 \pm 25$ & $29 \pm 10$ \\
\hline Homoarginine & $26 \pm 2$ & $297 \pm 45$ & $16 \pm 4$ \\
\hline 2-Amino-3-guanidinopropionate & $67 \pm 4$ & & $33 \pm 4$ \\
\hline \multicolumn{4}{|l|}{ Miscellaneous } \\
\hline D-Arginine & $31 \pm 4$ & $340 \pm 53$ & $32 \pm 5$ \\
\hline
\end{tabular}

$\left(N^{\mathrm{G}}\right.$-nitroarginine) resulted in very little inhibition. Modification of the methylene side chain of arginine, as in L-homoarginine and L-canavanine, resulted in strong inhibition of arginine uptake. Non-polar amino acids such as L-norvaline and L-alanine did not inhibit arginine uptake. Finally, the D-isomer of arginine appeared to interact with the arginine transporter.

Graphical determination of inhibitor constants $\left(K_{i}\right)$ from Hunter \& Downs (1945) plots showed that the six analogues chosen were all competitive inhibitors of arginine uptake. The $K_{\mathrm{i}}$ values for these analogues are shown in Table 2. $N^{\mathrm{G}}$-Methyl-L-arginine appeared to be an excellent ligand for the arginine transporter, with a $K_{\mathbf{i}}$ of $18 \mu \mathrm{M}$, almost identical to the $K_{\mathrm{m}}$ for arginine uptake. Other analogues demonstrated $K_{\mathrm{i}}$ values ranging from $140 \mu \mathrm{M}$ for $\mathrm{L}$-canavanine to $340 \mu \mathrm{M}$ for $\mathrm{D}$-arginine.

\section{Arginine-ornithine exchange}

HPLC amino acid analysis was used to investigate the possibility of an arginine-ornithine antiport operating in G. intestinalis. The accumulation of a number of arginine analogues (at $1 \mathrm{mM}$ external concentration) was monitored at $25^{\circ} \mathrm{C}$ over a $4 \mathrm{~min}$ time period. The analogues chosen were those that were most effective in inhibiting arginine uptake. In addition any concomitant efflux of intracellular ornithine was measured. A rep- 


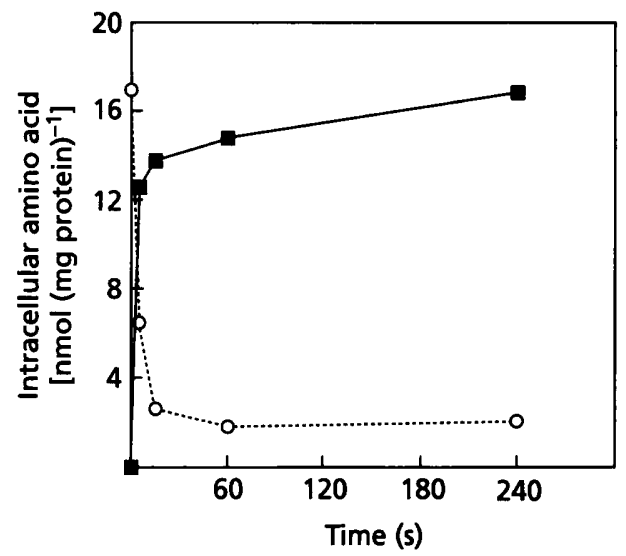

Fig. 2. Exchange of intracellular ornithine for extracellular $\boldsymbol{N}^{-}$methyllysine over a $240 \mathrm{~s}$ time period at $25^{\circ} \mathrm{C}$ by $\mathrm{G}$. intestinalis. Intact cells were incubated with $N^{e}$-methyllysine $(1 \mathrm{mM})$ and at specific time points the reaction mix was centrifuged through an oil layer into $20 \%(w / v)$ sulphosalicylic acid. After the addition of an internal standard, the intracellular concentrations of $\mathrm{N}^{\varepsilon}$-methyllysine $(\square)$ and ornithine $(O)$ were quantified by HPLC amino acid analysis. Values are means of duplicates.

resentative time course is shown in Fig. 2. The accumulation of arginine analogue over a $60 \mathrm{~s}$ time period and the corresponding efflux of intracellular ornithine are given in Table 3 , as is the ratio of analogue accumulated:ornithine effluxed over this time period. The four chosen analogues $\left(N^{G}\right.$-methylarginine, $N^{\varepsilon}$ methyllysine, D-arginine and L-homoarginine) were all accumulated by $G$. intestinalis over a 4 min time period. No evidence for metabolism of the analogues was observed over this period on the basis of amino acid analysis. However, amino acid analysis revealed that Lcanavanine was accumulated and subsequently metabolized by the parasite, to a compound that appeared to be the product of deamination by arginine deiminase. Therefore canavanine was not used in these exchange studies. The ratio of arginine analogue accumulated: ornithine effluxed at the $60 \mathrm{~s}$ time point was approximately 1.0 for all four non-metabolized analogues, suggesting the stoichiometric exchange of ornithine for arginine. The mean ratio for all experiments was $1.08 \pm 0.09(n=8)$. As negative controls, 4-guanidinobutyric acid and L-norvaline uptake was examined. 4 Guanidinobutyric acid, which does not compete for arginine uptake, was not accumulated, and as such there was no concomitant efflux of ornithine. L-Norvaline, which is also not an inhibitor of arginine uptake, was taken up by the cells, but there was no comcomitant release of intracellular ornithine.

\section{Kinetic studies of arginine deiminase}

The method of Prescott \& Jones (1969) was found to be of suitable sensitivity, in combination with short assay times $\left(2.5 \mathrm{~min}\right.$ at $\left.37^{\circ} \mathrm{C}\right)$ and $40-60 \mu \mathrm{g}$ protein in the enzyme assay. The activity of arginine deiminase over a concentration range of $0.07-1 \mathrm{mM}$ showed typical saturation kinetics. From three separate determinations, computer analysis based on the Michaelis-Menten equation gave a $K_{\mathrm{m}}$ of $0.16 \pm 0.06 \mathrm{mM}$ for arginine and a $V_{\max }$ of $547 \pm 124 \mathrm{nmol} \mathrm{m^{-1 }}$ (mg protein) ${ }^{-1}$. Assay linearity over $2.5 \mathrm{~min}$ was established at both the highest and lowest arginine concentrations. To determine the substrate specificity of arginine deiminase, inhibition experiments were performed in which the activity of arginine deiminase with $1 \mathrm{mM}$ arginine over a $10 \mathrm{~min}$ period at $37^{\circ} \mathrm{C}$ was monitored in the presence and absence of potential substrates ( $10 \mathrm{mM}$ final concentration). The results are shown in Table 2 . The overall pattern of inhibition of arginine deiminase was similar to that of arginine transport, but with a number of striking exceptions. L-Lysine was a poor inhibitor of arginine deiminase, but was a good inhibitor of arginine uptake.

Table 3. Amount of amino acid accumulated and ornithine effluxed from $G$. intestinalis trophozoites at $25^{\circ} \mathrm{C}$ over a $60 \mathrm{~s}$ time period

Intact trophozoites were incubated with the arginine analogue at a final concentration of $1 \mathrm{mM}$ for $60 \mathrm{~s}$ at $25^{\circ} \mathrm{C}$. The reaction mix was then centrifuged through an oil layer into $40 \mu \mathrm{l} 20 \%$ (w/v) sulphosalicylic acid to stop the reaction. After addition of an internal standard, the samples were analysed using a Beckman system 6300 amino acid analyser. Values are from two separate experiments.

\begin{tabular}{|lccc|}
\hline Amino acid & $\begin{array}{c}\text { Amino acid } \\
\text { influx } \\
\text { [nmol } \\
\text { (mg protein) })^{-1} \text { ] }\end{array}$ & $\begin{array}{c}\text { Ornithine } \\
\text { efflux } \\
\text { [nmol } \\
\text { (mg protein })^{-1} \text { ] }\end{array}$ & $\begin{array}{c}\text { Ratio } \\
\text { influx: efflux }\end{array}$ \\
\hline D-Arginine & $17 \cdot 4,21 \cdot 7$ & $18 \cdot 8,18 \cdot 6$ & $0 \cdot 93,1 \cdot 17$ \\
$N^{\varepsilon}$-Methylarginine & $10 \cdot 0,10 \cdot 8$ & $9 \cdot 0,9 \cdot 1$ & $1 \cdot 11,1 \cdot 19$ \\
$N^{\mathrm{G}}$-Methyllysine & $14 \cdot 8,19 \cdot 0$ & $15 \cdot 2,17 \cdot 7$ & $0 \cdot 97,1 \cdot 07$ \\
Homoarginine & $16 \cdot 5,21 \cdot 2$ & $15 \cdot 3,18 \cdot 7$ & $1 \cdot 08,1 \cdot 13$ \\
4-Guanidinobutyric acid & 0,0 & $0 \cdot 1,0$ & \\
Norvaline & $5 \cdot 2,2 \cdot 4$ & $0,0 \cdot 4$ & \\
\hline
\end{tabular}


$N^{\mathrm{G}}$-Nitroarginine, which gave little inhibition of arginine uptake, appeared to be a potent inhibitor of arginine deiminase. Finally, two of the best inhibitors of arginine uptake, $N^{G}$-methyl-L-arginine and $N^{\varepsilon}$-methyl-L-lysine, did not inhibit arginine deiminase.

\section{DISCUSSION}

L-Arginine is an important fuel in the overall energy metabolism of $G$. intestinalis (Edwards et al., 1992) and rapid flux through the arginine dihydrolase pathway requires a highly efficient transport system for the accumulation of arginine. Since L-arginine can be metabolized in $G$. intestinalis by the arginine dihydrolase pathway (Schofield et al., 1992), to distinguish between arginine transport and uptake, it was initially necessary to quantify the extent of metabolism over a representative time course. The observed rate of arginine metabolism was most unexpected, with $85 \%$ of the accumulated arginine being metabolized to citrulline within $4 \mathrm{~s}$, and $97 \%$ within $30 \mathrm{~s}$. However, further conversion of citrulline to ornithine was minimal. For uptake of radiolabel to be representative of transport of a radiolabelled molecule it is necessary either to have minimal metabolism of the transported molecule or to have complete metabolism to a compound (or compounds) that retain the label and are accumulated within the cell. Most investigations of transport try to adhere to the minimal metabolism criterion. However, the latter situation, which is equivalent to a coupled enzyme assay system, is equally valid. In this case, the activity of the second step, arginine deiminase, is far greater than that of the first step, the arginine transporter. Since less than $2 \%$ of the transported arginine had been metabolized to intracellular ornithine at the $4 \mathrm{~s}$ timepoint, with the remainder primarily as intracellular citrulline, the uptake of radiolabel from external ${ }^{3} \mathrm{H}$ was representative of arginine transport. Over longer time periods, some of the radiolabel was detectable as extracellular radiolabelled ornithine that had exchanged with the tranported arginine, but nonetheless only in small quantities (less than $20 \%$ of the accumulated radiolabel after $30 \mathrm{~s}$ ).

Our observations have demonstrated the presence of an arginine transporter with a high affinity for arginine $\left(K_{\mathrm{m}}\right.$ $15 \mu \mathrm{M})$ and large capacity $\left[V_{\max } 76 \mathrm{nmol} \mathrm{min}{ }^{-1}(\mathrm{mg}\right.$ protein $)^{-1}$ ] in G. intestinalis. Although some kinetic data are available for arginine transport in prokaryotes, the availability of comparative values for arginine transport in other parasitic protozoa is limited. The Trypanosomatidae family transport arginine via carrier-mediated mechanisms but all demonstrate affinities much lower than that reported here for Giardia, e.g. $K_{\mathrm{m}}$ values of $0.8 \mathrm{mM}$ for Trypanosoma lewisi (Manjra \& Dusanic, 1972) and $0.71 \mathrm{mM}$ for Trypanosoma gambiense (Hansen, 1979). Whereas these trypanosomatid arginine transport systems have a non-saturable component of influx, such a system does not appear to be present in $G$. intestinalis. With respect to other amino acid transport systems described from parasitic protozoa, the $G$. intestinalis arginine transporter displays the highest affinity and maximal velocity for its substrate (Fricker et al., 1984; Bonay \& Cohen, 1983; Law \& Mukkada, 1979). This may reflect the relative importance of arginine metabolism to the overall energy economy of $G$. intestinalis, compared to amino acid metabolism in these other parasites.

Substrate specificity studies indicated that there are three major structural parameters governing recognition of the transporter with the ligand. These factors are: (a) the presence of the $\alpha$-amino and $\alpha$-carboxyl moiety; (b) the distal basic group, and (c) the methylene chain length between this distal basic group and the $\alpha$-amino $\alpha$-carboxyl moiety. Blocking the $\alpha$-amino group, as in $N^{\alpha}$ acetylarginine and $N^{\alpha}$-carbamylarginine, prevents substrate recognition. Likewise, removal of the $\alpha$-carboxyl group, as in the diamines putrescine and agmatine, substantially reduces ligand recognition. The second parameter is the side chain length. For the naturally occurring amino acids, the two most effective as inhibitors are lysine ( 5 carbons between the groups) and ornithine (4 carbon chain). Further reduction of this chain length, to 2,4-diaminobutyric acid and 2,3-diaminopropionic acid, successively eliminates ligand recognition. The optimum chain length appears to be a span of 4 to 5 carbon atoms. The strong inhibition by homoarginine ( 5 carbon span) and canavanine (a 3 carbon span incorporating an ether linkage) are consistent with these binding requirements. Such a chain length criterion has also been described for mammalian arginine transport systems (White et al., 1982; White \& Christensen, 1982). The third principal parameter dictating recognition is the presence of a distal basic group. There appears to be some flexibility in this site since substitution of the guanidino group with an amino group does not prevent recognition (as in the case of ornithine and lysine). Substitution on the guanidino group itself results in diverse effects. Methylation, as in $N^{G}$-methylarginine, did not prevent ligand binding, which is also true for mammalian arginine transport (Bogle et al., 1992; Westergaard et al., 1993). However, substitution of the much bulkier and more polar nitro group, as in $N^{G}$-nitroarginine, prevents recognition, as is also the case for mammalian cells (Bogle et al., 1992; Westergaard et al., 1993). As to stereochemical requirements for substrate recognition, the $\mathrm{D}$-isomer of arginine competitively inhibited the transport of $\mathrm{L}$-arginine, albeit with a lower affinity for the binding site than the L-isomer, suggesting that spatial arrangement of the $\alpha$-carbon groups is not of crucial importance in ligand binding. Enzymic assay with octopine dehydrogenase ruled out the possibility that the activity exhibited by $\mathbf{D}$-arginine was due to contamination by L-arginine, and a nonmetabolized intracellular arginine pool appeared when trophozoites were incubated with $\mathrm{D}$-arginine. Overall, the ligand binding characteristics of the arginine transporter in $G$. intestinalis are very similar to those of mammalian cells. However, for protozoan parasites there have been very few inhibition studies to date, which prevents meaningful comparison with the giardial transporter.

From amino acid analysis, it appears that the arginine transporter is an arginine-ornithine antiport. Exchange between intracellular ornithine and a number of extra- 
cellular arginine analogues, including $N^{\mathrm{G}}$-methylarginine and homoarginine, was observed. In such studies, it was important to use non-metabolizable analogues and this was concurrently monitored by amino acid analysis. Over a $60 \mathrm{~s}$ time period, the amount of accumulated arginine analogue was equimolar with the amount of ornithine released from the cell. The stoichiometric arginine :ornithine exchange reported here is consistent with in vivo growth experiment results, showing that for each mole of arginine consumed from the medium, one mole of ornithine is released into the growth medium (Edwards et al., 1992). It is metabolically sensible for such a transport system to be operational in $G$. intestinalis, since the arginine dihydrolase pathway only produces one mole of ATP per mole of arginine consumed. Thus, a non-energy dependent transport system for arginine is not wasteful of the metabolic energy generated from the degradation of translocated arginine. Such an arginine-ornithine antiport has previously been demonstrated in the bacterium Streptococcus lactis, which also has a functional arginine dihydrolase pathway (Driessen et al., 1987).

Since the transported arginine was so rapidly metabolized by arginine deiminase, it was necessary to define the kinetic properties of this enzyme. Preliminary investigations using the chromogenic assay system of Boyde \& Rahmatullah (1980) for citrulline determination were unsatisfactory due to the insensitivity of this method at the low arginine concentrations required for the kinetic studies. The colorimetric assay of Prescott \& Jones (1969) was found to be more sensitive and reproducible, especially at the lower arginine concentrations used. Using this method, the $K_{m}$ of arginine deiminase for arginine was $0.16 \mathrm{mM}$. This is very similar to values published for this enzyme from other organisms, including Mycoplasma arginini (0.2 mM; Takaku et al., 1992), Pseudomonas putida $(0.2 \mathrm{mM}$; Shibatani et al., 1975) and Tetrabymena thermophila $\left(0.41 \mathrm{mM}\right.$; Eichler, 1989). The $V_{\max }$ of arginine deiminase found in this study was greater than values we have previously reported (Schofield et al., 1992); this observed increase is due to optimization of the assay conditions cited above. The individual $V_{\max }$ values for the three enzymes of the arginine dihydrolase pathway expressed as $\mathrm{nmol} \mathrm{\textrm {min } ^ { - 1 }}$ ( $\mathrm{mg}$ protein) $)^{-1}$ are: arginine deiminase, 550 (at $37^{\circ} \mathrm{C}$ ); ornithine transcarbamoylase, 170 (at $37^{\circ} \mathrm{C}$ ); and carbamate kinase, 2100 (at $30^{\circ} \mathrm{C}$ ). These activities are consistent with ornithine transcarbamoylase, and not arginine deiminase, being rate limiting and with the observed accumulation of citrulline in arginine uptake experiments.

The substrate specificity for arginine deiminase suggests that the same three structural constraints operating for the arginine transporter ligand binding also apply to substrate recognition for arginine deiminase from $G$. intestinalis. However, although there are some similarities in the binding requirements, there are also some marked differences. For the arginine deiminase, blocking or removal of the $\alpha$-amino group prevents recognition, but absence of the $\alpha$-carboxyl is tolerated in that agmatine and putrescine compete with arginine for the active site. Secondly, the carbon chain length between the guanidino group and the $\alpha$-amino $\alpha$-carboxyl moiety is not critical for enzyme activity. Shortening the chain length to two (2-amino-3-guanidinopropionic acid) and lengthening the carbon chain length to five (homoarginine) does not destroy recognition. Such binding requirements have been reported for arginine deiminase from Euglena gracilis (Park et al., 1984) and Pseudomonas putida (Shibatani et al., 1975), but they differ from those of the arginine deiminase of Mycoplasma artbritidis (Smith et al., 1978). However, when the distal basic group is an amino group, the chain length of the analogue is more critical. Recognition is optimal with a 3 to 4 carbon chain substrate, in that ornithine and 2,4-diaminobutyric acid inhibit arginine binding, whereas lysine and 2,3-diaminopropionic acid do not. Modification to the guanidino (or side chain amino) group seems to be the critical factor differentiating between arginine transport and arginine metabolism by arginine deiminase. $N^{\mathbb{G}}$-Nitroarginine potently inhibits arginine deiminase, whereas $N^{G}$-methylarginine (and $N^{\varepsilon}$ methyllysine) have no effect; for the transporter the opposite occurs. Clearly, these differential effects can be used to advantage in distinguishing between arginine transport and metabolism and their individual characteristics. Surprisingly, D-arginine is a ligand for arginine deiminase, implying that for the enzyme, like the transporter, stereochemical conformation is not crucial. However, D-arginine was not a substrate for arginine deiminase. A similar effect has been observed for arginine deiminase from E. gracilis (Park et al., 1984), but Darginine had no effect on the deiminase from $P$. putida (Shibatani et al., 1975) or M. artbritidis (Smith et al., 1978). Overall, the inhibition pattern of arginine deiminase from $G$. intestinalis closely resembles that reported for deiminases from prokaryotic organisms, suggesting that they have common structural requirements for catalytic activity.

In summary, the combination of the high-activity arginine transporter and the high affinity for arginine coupled to its operation as an arginine-ornithine antiport ensures substantial uptake of arginine for the rapid proliferative growth of $G$. intestinalis. These observations support the view that this protozoan parasite displays prokaryotic features, and occupies a transition between the prokaryotic and eukaryotic kingdoms.

\section{ACKNOWLEDGEMENTS}

This work was supported by a grant from the National Health and Medical Research Council of Australia. L.A.K. is the recipient of a Dora Lush (Biomedical) Postgraduate Scholarship. We thank Mr G. Grossman for his skilled technical assistance.

\section{REFERENCES}

Bogle, R. G., Moncada, S., Pearson, J. D. \& Mann, G. E. (1992). Identification of inhibitors of nitric oxide synthase that do not interact with the endothelial cell L-arginine transporter. $\mathrm{Br} J$ Pharmacol 105, 768-770.

Bonay, P. \& Cohen, B. E. (1983). Neutral amino acid transport in Leishmania promastigotes. Biochim Biophys Acta 731, 222-228. 
Bourdineaud, J. P., Heierli, D., Gamper, M., Verhoogt, H. J. C., Driessen, A. J. M., Konings, W. N., Lazdunski, C. \& Haas, D. (1993). Characterization of the $\operatorname{arcD}$ arginine: ornithine exchanger of Pseudomonas aeruginosa. J Biol Chem 268, 5417-5424.

Boyde, T.R. C. \& Rahmatullah, M. (1980). Optimization of conditions for colorimetric determination of citrulline, using diacetyl monoxime. Anal Biochem 107, 424-431.

Bradford, M. M. (1976). A rapid and sensitive method for the quantitation of microgram quantities of protein utilizing the principle of protein-dye binding. Anal Biocbem 72, 248-254.

Cunin, R., Glansdorff, N., Piérard, A. \& Stalon, V. (1986). Biosynthesis and metabolism of arginine in bacteria. Microbiol Rev 50, 314-352.

Driessen, A. J. M., Poolman, B., Kiewiet, R. \& Konings, W. N. (1987). Arginine transport in Streptococcus lactis is catalyzed by a cationic exchanger. Proc Natl Acad Sci US A 84, 6093-6097.

Edwards, M. R., Schofield, P. J., O'Sullivan, W. J. \& Costello, M. (1992). Arginine metabolism during culture of Giardia intestinalis. Mol Biochem Parasitol 53, 97-104.

Edwards, M. R., Knodler, L. A., Wilson, J. R. \& Schofield, P. J. (1993). The transport and metabolism of alanine by Giardia intestinalis. Mol Biochem Parasitol 61, 49-58.

Eichler, W. (1989). Inhibition of L-arginine iminohydrolase (EC 3.5.3.6) from Tetrabymena thermophila by putrescine and spermidine: feedback control of polyamine biosynthesis. Biol Chem Hoppe-Seyler 370, 1127-1131.

Fricker, S. P., Jones, S. E. M., Ellory, C., Angus, J. M. \& Klein, R. A. (1984). Threonine uptake in Trypanosoma brucei. Mol Biochem Parasitol 11, 215-223.

Hansen, B. D. (1979). Trypanosoma gambiense: membrane transport of amino acids. Exp Parasitol 48, 296-304.

Hunter, A. \& Downs, C. E. (1945). The inhibition of arginase by amino acids. $J$ Biol Chem 157, 427-446.

Knodler, L. A., Edwards, M. R. \& Schofield, P. J. (1994). The intracellular amino acid pools of Giardia intestinalis, Trichomonas vaginalis and Crithidia luciliae. Exp Parasitol 79, 117-125.

Law, S. S. \& Mukkada, A. J. (1979). Transport of L-proline and its regulation in Leishmania tropica promastigotes. J Protozool 26, 295-301.
Manjra, A. A. \& Dusanic, D. G. (1972). Mechanisms of amino acid transport in Trypanosoma lewisi. Comp Biochem Pbysiol 41A, 897-903.

Park, B. S., Hirotani, A., Nakano, Y. \& Kitaoka, S. (1984). Purification and some properties of arginine deiminase in Euglena gracilis Z. Agric Biol Chem 48, 483-489.

Prescott, L. M. \& Jones, M. E. (1969). Modified methods for the determination of carbamyl-aspartate. Anal Biochem 32, 408-419.

Schofield, P. J., Edwards, M. R., Matthews, J. \& Wilson, J. (1992). The pathway of arginine catabolism in Giardia intestinalis. Mol Biochem Parasitol 51, 29-36.

Shibatani, T., Kakimoto, T. \& Chibati, I. (1975). Crystallization and properties of L-arginine deiminase of Pseudomonas putida.J Biol Chem 250, 4580-4583.

Smith, D. W., Ganaway, R. L. \& Fahrney, D. E. (1978). Arginine deiminase from Mycoplasma artbritidis. J Biol Chem 253, 6016-6020.

Sogin, M. L., Gunderson, J. H., Elwood, H. J., Alonso, R. A. \& Peattie, D. A. (1989). Phylogenetic meaning of the kingdom concept: an unusual ribosomal RNA from Giardia lamblia. Science $243,75-77$.

Takaku, H., Takase, M., Abe, S., Hayashi, H. \& Miyazaki, K. (1992). In vivo anti-tumor activity of arginine deiminase purified from Mycoplasma arginini. Int J Cancer 51, 244-249.

Westergaard, N., Beart, P. M. \& Schousboe, A. (1993). Transport of $\mathrm{L}-\left[{ }^{3} \mathrm{H}\right]$ arginine in cultured neurons: characteristics and inhibition by nitric oxide synthase inhibitors. $J$ Neurocbem $61,364-367$.

White, M. F. (1985). The transport of cationic amino acids across the plasma membrane of mammalian cells. Biochim Biophys Acta 822, 355-374.

White, M. F. \& Christensen, H. N. (1982). Cationic amino acid transport into cultured animal cells. II. Transport system barely perceptible in ordinary hepatocytes, but active in hepatoma cell lines. $J$ Biol Chem 257, 4450-4457.

White, M. F., Gazzola, G. C. \& Christensen, H. N. (1982). Cationic amino acid transport into cultured animal cells. I. Influx into cultured fibroblasts. J Biol Chem 257, 4443-4449.

Received 30 December 1994; revised 18 April 1995; accepted 1 May 1995. 